\title{
Sexo com animais como prática extrema no pornô bizarro*
}

\author{
María Elvira Díaz-Benítez
}

\section{Resumo}

Dentro do segmento do mercado pornô conhecido como bizarro, a prática considerada extrema por excelência é alocada ao sexo com animais. O Brasil possui uma indústria de produção desses filmes reconhecida mundialmente. Este artigo discute o estigma dessas produções no interior da indústria pornô, traz dados etnográficos sobre a produção desse mercado, introduz uma discussão sobre legalidade, consentimento e direitos, e finalmente, trata essa temática do ponto de vista do erotismo e dos prazeres pensando o lugar do gênero e da sexualidade nessas práticas. Acredita-se que a temática é um campo vasto para pensarmos as relações humano/animal, normal/anormal, prazer/perigo, natureza/cultura.

Palavras-chave: Sexo Bizarro, Indústria Pornô, Erotismo.

\footnotetext{
" Recebido para publicação em 02 de outubro de 2011, aceito em 01 de novembro de 2011. Para a elaboração deste artigo, foram de grande colaboração as críticas $e$ sugestões que recebi dos participantes do grupo Sexualidade $e$ gênero: sociabilidade, erotismo e política, da Anpocs, especialmente as de Sérgio Carrara, Isadora França, Regina Facchini, Luiz Fernando Dias Duarte e Carolina Branco. Agradeço a Guilherme Antunes, Roberto Efrem e Eder Parladore pela sugestão de bibliografia, pela troca de ideias e pelos esclarecimentos a respeito de leis e estatutos jurídicos sobre os direitos dos animais. Outras dicas importantes vieram de Adriana Piscitelli, Laura Lowekron, Christiano Tambascia, Jonathan Jackson, Rafael Gutiérrez e José Ramón Diaz Benítez, aos quais sou igualmente grata. Finalmente, um agradecimento muito especial para Jorge Leite Jr. e para Maria Filomena Gregori, meus principais interlocutores.

** Pesquisadora colaboradora do Núcleo de Estudos de Gênero - Pagu/Unicamp e pós-doutoranda no Instituto de Filosofia e Ciências Sociais da mesma universidade, com financiamento da Fundação de Amparo à Pesquisa do Estado de São Paulo (FAPESP). elviradiazbenitez@hotmail.com
}

cadernos pagu (38), janeiro-junho de 2012:241-279. 
Sexo com animais como prática extrema no pornô bizarro

Sex with Animals as an

Extreme Practice in Bizarre Porn

\begin{abstract}
Within the bizarre porn market, the extreme practice is that of sex with animals. Brazil has a worldwide known industry producing this kind of porn. This paper discusses the stigma associated to this kind of production within the porn industry, adds ethnographic data on this market's production, introduces a discussion on the legality, consent and rights and treats the theme from the point of view of eroticism and pleasure, thinking about gender and sexuality in these practices. The question is seen as a vast field to think about dyadic relations like human/animal, normal/abnormal, pleasure/danger, nature/culture.
\end{abstract}

Key Words: Bizarre Sex, Porn Industry, Eroticism. 
Especialmente a partir da vocação taxonômica da medicina, mas encontrando fios de transmissão e retroalimentação em outros aparelhos ideológicos, como a família, a escola, a religião, a imprensa, a literatura, os manuais de sexualidade e de moral $e$ boa conduta, muitos comportamentos foram instituídos na ilegitimidade como sexualidades periféricas. A primeira sexologia que data do final do século XIX até o início do XX, a partir do esforço do psiquiatra alemão Richard Von Krafft Ebing em classificar as sexualidades que desafiavam a norma reprodutiva heterossexual criou dois movimentos: a patologização dos personagens, que deixavam de ser criminosos ou pecadores para serem percebidos como doentes a serem tratados, e a naturalização dos comportamentos ditos "perversos", ou seja, a afirmação de que se tratava de pessoas biológica ou fisiologicamente diferentes (Russo, 2004). A maioria das pesquisas sobre as sexualidades "perversas" é proveniente da tradição sexológica e tem insistido na catalogação de tais práticas como parafilias e na "cura" desses prazeres. Simultaneamente, grande parte dessas parafilias - como a riparofilia (atração sexual por mulheres sujas, menstruadas ou grávidas), o exibicionismo, o fetichismo, o sadismo, o masoquismo, o bestialismo ou zoofilia, a lubricidade senil, a cronoinversão (jovens que amam pessoas idosas), a gerontofilia aparece no pornô, sob o viés do entretenimento, em dois segmentos conhecidos como fetiche e bizarro.

Entre as práticas que o mercado pornô promove dentro dessas noções, encontramos condutas que, no século XIX, se constituíram como diagnósticos de desvios sexuais: o sadismo, o masoquismo e o fetichismo, por exemplo. Atualmente, o pornô enquadra nestas categorias práticas que enfatizam a dor física dos indivíduos envolvidos em uma relação sexual: spanking (golpes ou açoites no corpo), bondage (imobilização com cordas ou outros objetos) e sufocações diversas, como a chamada smoother (asfixia dos genitais). São representados no pomô outros tipos de sufocações eróticas que se efetuam com as mãos, com cordas, gravatas ou meias-calças segundos antes de se alcançar o orgasmo ou durante 
o mesmo. Além destas, também se verificam sufocações que consistem na obstrução da respiração mediante a alocação das nádegas sobre o rosto do contracenante em momentos alheios à consumação de uma transa ou independentemente da efetivação de um intercurso sexual em si. Algumas dessas práticas são efetivadas no altporn ou pornô alternativo ou ainda na categoria emergente, denominada pornô kink.

As estéticas mais comumente associadas às práticas sexuais bizarras são aquelas que fazem uso de secreções e excrementos corporais. Entre estas, a chuva dourada (erotismo com urina), conhecido atualmente no mercado como pissing, é considerada "leve" nesse universo, sendo catalogado como extremo o banho romano, hoje chamado de vomit (erotismo com vômito) e o banho marrom, mais conhecido como scat (erotismo com fezes). Finalmente, no pornô, a prática bizarra por excelência é adjudicada ao sexo com animais, chamada nesse mercado de zoofilia.

O pornô bizarro espetaculariza os corpos em situações "prodigiosas" e incomuns, expondo objetos diversos (vegetais ou garrafas, entre outros), de grandes proporções, penetrando vaginas, ânus, bocas e canais da uretra (o fist fuck, por exemplo, penetração anal que se efetua introduzindo o punho, algumas vezes até a altura do cotovelo). Esse segmento enfatiza igualmente a extrema elasticidade da genitália feminina e do ânus; exibe pênis de formas estranhas; masturbações com objetos aspiradores; adoração de alguma parte do corpo; sexo com mulheres grávidas etc.

Em muitos filmes da categoria não existe penetração nem se enfatiza qualquer tipo de interação com a genitália. Neles, são estabelecidos jogos e deslocamentos mediante a utilização de qualquer parte do corpo como instrumento sexual, evocando-se uma "desgenitalização do prazer", na busca por novas formas de deleite a partir da fetichização de objetos ou partes do corpo não usuais.

Da perspectiva das corporalidades, por sua vez, têm lugar no pornô bizarro os corpos estranhos ou "anômalos": anões ou pessoas às quais falta alguma extremidade, além dos "deformados" por intervenções voluntárias como os 
exageradamente tatuados ou perfurados com piercings - estes últimos integrando igualmente estéticas do pornô alternativo. $\mathrm{O}$ pornô bizarro também dá lugar a corpos que sem serem "anormais", divergem dos padrões hegemônicos de beleza: pessoas obesas, idosas, exageradamente peludas e mulheres de seios muito grandes, entre outros.

Embora bizarro e fetiche não sejam palavras sinônimas, em alguns momentos seus significados podem entrecruzar-se ou mesmo confundir-se na indústria pornô. Quanto mais extrema for a prática encenada nos filmes, quanto maior for sua capacidade de despertar o nojo, maior a possibilidade de se aproximar do considerado bizarro. Ainda assim, nessas redes, a escatologia, tida como uma prática extrema, é chamada por uns de fetiche e de bizarra por outros. Pessoas gordas ou anãs, por exemplo, são consideradas corporalidades bizarras e, simultaneamente, seu apelo erótico é considerado produto de um fetiche. De alguma forma, o bizarro engloba o fetiche, sendo que este último não necessariamente chega a ser bizarro.

Muitas dessas representações são geralmente encaradas como comédia: são bizarras porque despertam riso, o humor sendo parte integrante desse universo. Pelo fato de serem diferentes dos padrões estéticos dominantes, elas ajudam a tornar a pornografia mais incômoda diante dos discursos legítimos sobre a sexualidade. Assim, o riso somado a corpos e práticas socialmente deslegitimados traz efeitos simbólicos que concorrem para a sua desqualificação. Anões, idosos, mulheres peitudas, obesas ou peludas são os corpos preferidos do paradigma do riso, enfatizado nos títulos e legendas que acompanham os filmes. ${ }^{1}$

Em geral, o discurso levantado pela imagem pornô sobre o exagero e o realismo das práticas é levado ao extremo no segmento bizarro.

1 Títulos como Gostosonas (série de mulheres obesas), Vovô é foda (protagonizado por mulheres idosas), Sugando tudo (em cuja capa há uma mulher jovem fazendo sexo oral em um idoso magérrimo), $O$ clube das peludas (com mulheres com vaginas repletas de pelos) e Aquiles sex machine (cujo protagonista é um anão vestido de punk) etc. 
Sexo com animais como prática extrema no pornô bizarro

Por um lado, trata-se de mostrar corpos que transgridem as convenções sociais do "normal" e do "sadio". Por outro, há por detrás da exibição das imagens, a intenção de impressionar e incomodar o público, excitando somente aqueles que encontram prazer no não usual, naquilo que escapa do "cotidiano".

Segundo o antropólogo Jorge Leite Jr. (2006a), as tendências que compõem o pornô bizarro poderiam ser entendidas em uma estética do grotesco, sendo herdeiras dos espetáculos de "aberrações humanas" e freak shows. Grotesco é uma categoria-chave para a interpretação do pornô bizarro. $\mathrm{O}$ grotesco une o exagero, as desproporções corporais (focando em suas protuberâncias e excreções) (Leite, 2006a), o riso e o horror. $\mathrm{O}$ termo, surgido no século $\mathrm{XV}$, dava nome a seres que eram misturas de humanos, plantas $e$ animais $e$ outras formas impossíveis, tendo a monstruosidade como tema (id.ib.:174). Já no século XVII, o grotesco aparece nos dicionários franceses como "aquilo que tem algo de agradavelmente ridículo além de sinônimo de ridículo, bizarro, extravagante" (Sodré e Paiva, 2002:30 apud Leite, 2006a:176), mas é mesmo no século XIX que o grotesco se torna uma categoria estética que visa representar o sublime através do degradado, contendo ainda a dualidade entre o cômico e o horrível em seu significado.

Enfim, o grotesco evoca o riso e o ridículo e, ao mesmo tempo, o medo, o sinistro, o nojento e o horror. É nestas duas últimas características desse paradigma estético que se situaria o pornô com animais. Ele não evoca o burlesco, não faz alegorias ao cômico, não abre espaços para o riso. Seus enunciados aproximam-se mais do horror, é por isso que ele é considerado hard, radical ou bizarro por excelência.

\section{Por que pesquisar pornografia com animais?}

Escrever um artigo sobre práticas sexuais entre humanos $e$ animais não constitui uma tarefa fácil. Não somente porque trabalho com dados que resultam de uma etnografia que, em 
alguma medida, mexe com meus próprios pudores, mas também porque se trata de um tema delicado, que choca sensibilidades. Aquilo que foi chamado por Krafft Ebing de zoofilia é um tabu social e aqueles que ostentam esses desejos ou exercem tais práticas são socialmente interpretados como doentes e/ou perversos. Essa é uma visão apoiada em crenças judaico-cristãs (com base nos versículos 18:23 e 20:15-16 do Levítico) e nas ciências psi: atualmente, a zoofilia aparece caracterizada no DSMIV como parafilia não especificada. ${ }^{2}$

Ao longo deste artigo, não me referirei à prática sexual em questão como zoofilia, não só para me afastar da visão patologizante que configura o termo, mas também porque acredito que os filmes de pornô com animais não estão necessariamente atrelados a uma "sensibilidade zoófila", como argumentarei adiante. Assim, quando a palavra zoofilia aparecer será somente para denotar o modo como a prática é nomeada no mercado pornô.

O sexo com animais é um tema sensível porque permanece nos interstícios, nas fronteiras do que se considera sadio, nos limites da sexualidade (Gregori, 2010). Enquanto alguns afirmam a possibilidade de uma conexão sexual prazerosa e harmônica entre humanos e animais, outros a interpretarão como abuso uma vez que o animal não tem capacidade para consentir. Outras pessoas ainda, ao assistirem essa pornografia, poderão interpretá-la como uma forma de degradação da mulher. E assim, eu me enfrento à necessidade de escrever um artigo sobre um tema que poderia ser abordado de perspectivas diversas: poderia enfatizar o estigma

2 No DSM-IV, Manual Diagnóstico e Estatístico dos Transtornos Mentais, da American Physiatric Association, a zoofilia aparece como F65.9 Parafilia não especificada (302.9). Citando o manual: "Esta categoria codifica as parafilias que não cumprem os critérios para nenhuma das categorias específicas. Como exemplos destas parafilias, cabe mencionar (embora não se limitem a): a escatologia telefônica (ligações obscenas), a necrofilia (cadáveres), o parcialismo (atenção centrada exclusivamente em uma parte do corpo), a zoofilia (animais), a coprofilia (fezes), a clismafilia (enemas) e a urofilia (urina)" (p. 586). 
Sexo com animais como prática extrema no pornô bizarro

dessas produções no interior da indústria pornô; realizar uma etnografia da produção desse mercado; adentrar a discussão sobre legalidade, consentimento e direitos (analisando categorias como crueldade e abuso); ou ainda, sublinhar a temática do ponto de vista do erotismo e dos prazeres (pensando o lugar do gênero e da sexualidade nessas práticas). Escolhi discutir um pouco de tudo isso, tendo consciência de que algumas questões precisarão ser abordadas com maior profundidade no futuro. Escrevo este artigo como uma primeira tentativa pessoal de analisar uma temática demasiado complexa.

Recentemente, em uma apresentação pública sobre os avanços de minha pesquisa, fui interpelada acerca dos problemas éticos envolvidos em uma etnografia de sexo com animais. Estaria eu, como antropóloga, fazendo apologia a uma prática de legalidade duvidosa e socialmente amoral? Sugeriram-me. Essa é uma discussão importante na antropologia: qual o limite de nossa observação? Existem temas que não merecem ser estudados? E a decisão de estudá-los significaria de algum modo defendê-los? A pornografia com animais existe: alguns a produzem para que outros a consumam. Trata-se de um material que circula como uma mercadoria, que agencia uma rede complexa de recursos, emoções e expectativas, e que pode constituir um vasto campo para pensarmos as relações humano/animal, normal/anormal, prazer/perigo, natureza/cultura. Em minha opinião, esses são motivos suficientes para que mereça uma análise antropológica.

Assim, esta pesquisa sobre sexo com animais decorre de uma pesquisa maior sobre pornô bizarro que, por sua vez, constitui um desdobramento de um estudo sobre os bastidores da indústria pornográfica brasileira de filmes hetero, gay e travesti. Naquela etnografia (Díaz-Benítez, 2010), o bizarro aparecia recorrentemente nos discursos das pessoas em contraposição ao tipo de material por eles produzido e considerado mainstream. A sistemática desqualificação da pornografia bizarra e dos indivíduos que dela participavam demonstrava que ali estaria alocada a ideia de uma "transgressão verdadeira". O bizarro era aquilo que 
chocava os limites da moralidade coletiva entre os praticantes da pornografia - que, de uma perspectiva mais geral, pode ser interpretada como uma atividade que desafia, por si só, determinados valores morais.

Por conseguinte, o ingresso nas produções bizarras está rodeado de limites. Dentro desse circuito existem diversas normas que, a seu modo, conseguem regular os comportamentos sexuais das pessoas que por ele transitam. Nas redes do pornô, que estão longe de constituir um universo desregulado, no qual os indivíduos podem experimentar as formas mais "esquisitas" de prazer, há uma espécie de moderador silencioso que vigia a incursão das pessoas nas experimentações por elas consideradas mais extremas. Aquelas que transgridem a moral reguladora destas redes sofrem a estigmatização de seus pares, dificilmente conseguindo deslanchar na carreira e sendo preferencialmente (às vezes exclusivamente) requisitadas para as produções mais "baixas". No pior dos casos, as portas da indústria lhes são definitivamente fechadas.

De acordo com valores coletivos, as bizarrices são qualificadas em função de sua maior ou menor "condenabilidade". As atrizes são os principais alvos de vigilância a esse respeito, pelo fato de serem os principais sujeitos no exercício dessas práticas, mas também porque a sexualidade feminina tem sido historicamente sujeita a maiores interdições, $e$ as redes da pornografia, para além das câmeras, não constituem uma exceção a essa regra.

Sendo assim, a maior das infrações identificada pelo coletivo consiste em fazer sexo com animais. Constantemente, os próprios atores e atrizes pornôs manifestam sua repulsa diante da possibilidade de exercerem tal prática. Alguns, inclusive, demonstram desconfiança em contracenar, ainda mais sem camisinha, com uma pessoa que a tenha praticado. Para vários, tal desconfiança passa por razóes de higiene, pelo risco de contaminação real com algum vírus contido no corpo do animal. Outros opinam que a pessoa que transa com animais não possui 
Sexo com animais como prática extrema no pornô bizarro

escrúpulos, sendo prejudicial para a imagem do pornô. Comparativamente, as atrizes que participam desse tipo de filmes queimam suas carreiras em uma velocidade bem maior que as demais. Para diretores e empresários, elas deixam de ser úteis, pois "mancham" a imagem da produtora, não devendo - pelo menos idealmente - ser novamente incluídas em filmagens mais convencionais da pornografia. Os realizadores explicam que o mercado internacional para o qual se dirige a distribuição tem como base a especialização dos elencos em determinadas práticas, separando os performers do bizarro dos performers de filmes hetero, e assim sucessivamente, não tolerando seu trânsito entre os diversos segmentos.

Aqueles que praticam ou atuam na produção de filmes de sexo com animais são os outsiders do pornô, que chegam a ser percebidos como anômalos, sendo de algum modo marginalizados e permanecendo "fora do círculo de membros 'normais' do grupo" (Becker, 1971:25). São aqueles que poluem, contagiam, que devem ser evitados, "matéria fora do lugar" (Douglas, 1991), e sobre eles recai a força do estigma. Segundo Becker (1971), espera-se que o desviante possua todos os traços auxiliares de seu desvio, todos os traços indesejáveis, inclusive em outros aspectos, como por exemplo, espera-se que um ladrão também seja capaz de matar. No circuito pornô, as atrizes que fazem sexo com animais são recorrentemente identificadas como usuárias assíduas de drogas, vistas como pessoas que perderam o controle de seus atos devido ao uso de tóxicos, ou que exercem tais práticas justamente para sustentar seu consumo. Na verdade, o coletivo estabelece uma diferença que, de algum modo, funciona para "perdoar" ou "negociar" os desvios, separando aquelas que fazem um filme com animais uma única vez (às vezes por desinformação ou porque a própria dinâmica da indústria terminou arrastando-as até ali) daquelas que o fazem recorrentemente. Estas últimas são, na realidade, as pessoas tidas como aquelas que sentem satisfação sexual ao realizarem tais atos, e tal identificação com o prazer, simbolicamente, as converte em mais perigosas. 
Por sua vez, há também pessoas que, sem terem participado previamente da pornografia, isto é, sem serem atrizes ou atores já conhecidos na rede, protagonizam filmagens com animais. Como não pertencem ao circuito $e$, portanto, não representam um perigo direto de contaminação nem ameaçam os esquemas morais do grupo, são comumente identificados como pessoas que efetivamente sentem excitação e prazer em exercer esse tipo de prática. Também costumam ser vistos como pessoas que enfrentam grandes dificuldades econômicas, desempenhando tal atividade por extrema necessidade. Por fim, recai sobre eles o estigma do vício em drogas, não existindo possibilidades de que comecem, a partir dali, uma carreira efetiva como atores/atrizes pornô.

Por meio desses discursos, a rede controla o sexo, etiqueta e classifica os comportamentos como perversões, marca fronteiras para o prazer e determina o que é e o que não é lícito, exercendo um controle do corpo social, parafraseando Foucault (1991). Vemos assim que o sexo com animais alude ao espaço do horror mesmo entre as pessoas que produzem pornô.

Isto não quer dizer que sua produção seja pequena. Em minha etnografia anterior, verifiquei que o Brasil era considerado o principal produtor mundial de pornô com animais - pelo menos, era isso que diziam os integrantes dessa indústria e que revelavam os inúmeros sites, estrangeiros em sua maioria, nos quais eram veiculados filmes nacionais desse tipo de pornô.

A era dourada das filmagens de pornô com animais no Brasil data do começo da década de 2000, momento em que um diretor holandês se instalou no país com o objetivo de produzir este filáo. ${ }^{3}$ Alugando chácaras e sítios na região metropolitana de

\footnotetext{
${ }^{3}$ Vale a pena lembrar que os prazeres entre humanos e animais no cinema não são um invento do pornô. São diversos os filmes que retratam relações afetivo/sexuais entre membros de ambas as espécies, as décadas de 1970 e 1980 sendo particularmente ricas nessas representações. Vale lembrar de King Kong, filme estreado em 1933, no qual o famoso gorila da Ilha da Caveira se apaixona por Anne Darrow, chegando a morrer metralhado em cima do Empire State, logo após carregar sua amada com a mão esquerda, naquela famosa cena que se
} 
converteu em um ícone da sétima arte. Pink Flamingos, de 1972, dirigido por John Waters, dentro de uma estética trash, narra a história de uma diva drag, chamada Divine, considerada a "pessoa mais nojenta do mundo". Neste filme foram postos em cena vários tabus: estupro, incesto, fetichismo, voyeurismo, escatologia e finalmente zoofilia, em uma única cena na qual um casal faz sexo com galinhas. Everything you always wanted to know about sex but were afraid to ask, de Woody Allen (1972), narra a história de um doutor que se apaixona por uma ovelha. Em 1973, o dramaturgo britânico Peter Shaffer escreveu Equus, peça que relata a relação entre um psiquiatra e um adolescente que sente fascinação sexual quase mística por cavalos. A obra foi levada ao cinema em 1977 e dirigida por Sidney Lumet. A obra La Bête (1974), de Walerian Borowczyk, narra a história de uma mulher que rechaça as investidas de uma besta, mas que, ao ser estuprada por ela, experimenta enormes prazeres ocasionados pela agressividade do ato. No filme Calígula, do diretor Tinto Bras, de 1979, já apareciam insinuantes episódios sexuais incluindo animais dentro dos prazeres e excentricidades protagonizados por aquele imperador. Em 1986, o diretor Nagisa Oshima lançou Max, Mon Amour, história que retrata as tensões de um casamento no momento em que o marido descobre que sua mulher, Margaret, tem como amante um chimpanzé chamado Max, e que ambos estão vivenciando uma atração extraordinária. No filme Emanuelle in América, do diretor Joe D'Amato (1977), por sua vez, foi retratada uma cena sexual entre uma mulher e um cavalo. É notório que, enquanto no cinema convencional diminuíram, nos últimos vinte anos, as histórias que narravam esse tipo de relações, o cinema pornô, que gravita em torno dessas mesmas histórias, se consolidou e as converteu em um fecundo segmento do mercado. Nesse crescimento, o Brasil ocupa um lugar de destaque, a partir da década de 1980, que colocou em cena uma filmografia herdeira do Cinema da Boca na qual o erotismo entre humanos (especialmente mulheres) $e$ animais (especialmente cavalos e cachorros) era o centro das narrativas. O filme Mulher Mulher, de Jean Garret (1977), pode ser considerado o precursor desta temática, ao mostrar uma única cena em que um cavalo lambe os seios de uma mulher. Ao longo da década de 1980, o diretor Juan Bajon produziu um total de 11 filmes que contemplavam a fantasia feminina de fazer sexo com cavalos. Nessa época, a atriz Sandra Moirelles ficou conhecida por suas famosas cenas eróticas com animais. O filme 24 horas de sexo explícito, de José Mojica Marins (1985), também incluiu cenas em que, apesar de o sexo entre pessoas e animais não ser explícito como o restante das práticas, era claramente insinuado em meio a pitadas de humor. Sua continuação, o filme 48 horas de sexo alucinante, do mesmo diretor (1987), seguiu a mesma fórmula, mudando o foco para o sexo explícito entre um homem e uma mulher encarnando o corpo de um touro e de uma vaca. Nesse meio tempo, em 1986, foi lançado o filme Alucinações sexuais de um macaco (Custódio Gomes, 1986), que retrata as fantasias sexuais de uma 
São Paulo e na Serra da Cantareira, tal diretor e sua equipe produziam em média cinco filmes por dia. O elenco mudava rapidamente, a estrutura da indústria lhes permitia contar com pessoas diversas, que eram recrutadas especificamente para filmes com animais ou já gravavam para filmes do pornô convencional nacional. Embora se produzissem cenas nas quais homens transavam com animais, a ênfase recaía nas mulheres como protagonistas: a dupla mulher/animal foi e continua sendo a fórmula básica desse mercado. Desde aquela época, as travestis também possuem um espaço nesse segmento do pornô, pois suas produções eram $e$ ainda são requisitadas no mercado transnacional. De fato, a principal assistente da equipe do holandês era uma travesti que colaborava tanto no recrutamento do elenco, quanto na execução das práticas sexuais diante das câmeras.

Além dessa equipe que é reconhecida na rede do pornô como a principal no ramo dos animais, outros produtores nacionais investiram, já naquela época, nesse segmento. Algumas das principais produtoras que comercializavam esse tipo de filmes mudavam os nomes de seus selos para não serem necessariamente identificadas como produtoras, mas tão somente como distribuidoras. Embora esses materiais fossem divulgados de modo aberto em locadoras, nos sites de algumas empresas (nacionais $e$ internacionais) e em camelôs, sua produção era feita respeitando um enome sigilo. Eles sofriam perseguição e esse foi o principal motivo pelo qual o holandês teve de abandonar o Brasil. Contudo, é comum encontrar seus velhos produtos ainda no mercado e dizem que periodicamente volta, por curtas temporadas, para gravar novas cenas. Como ele, outras equipes estrangeiras se hospedam no país temporariamente perseguindo o mesmo objetivo, ou contratam produtores nacionais para fazê-lo, o que faz com que - mesmo com uma frequência bem menor e em meio a muito sigilo - a

mulher com esse animal (desta vez fake, personificado pelo ator conhecido como Chumbinho da Boca do Lixo). Finalmente, o filme Mulheres taradas por animais, do diretor Ody Fraga, de 1989, destaca-se por somar ao repertório de animais convencionais uma anta e um leão. 
Sexo com animais como prática extrema no pornô bizarro

produção nacional permaneça na ativa com sua estrutura: diretores, locações de filmagem e destinos de distribuição.

No entanto, não é mais possível afirmar que o Brasil seja o principal produtor mundial de filmes pornô com animais. Aparentemente esse papel passou a ser ocupado por países asiáticos. Mas por que a insistência do mercado pornô em associar o Brasil à zoofilia? É uma pergunta que mesmo após um longo tempo de pesquisa, ainda não consigo responder com exatidão. Este artigo é uma tentativa de trazer algumas pistas.

\section{Entre embates morais e ambiguidades jurídicas}

Um importante motivo de estigma ao redor da produção de filmes com animais relaciona-se com a crença coletiva que qualifica esta prática e sua comercialização como ilegais. Contudo, as ideias a esse respeito são confusas. Embora muitos suponham que o pornô com animais deva ser legal, já que é distribuído de modo não clandestino, também persiste a crença - entre as próprias pessoas da rede - de que sua legalidade não é, digamos, total. Em sua argumentação, alguns aludem à Sociedade Protetora de Animais, mas nunca conseguem fazer referência a leis ou decretos específicos elaborados por tal entidade. Existe também a crença de que o comércio desses filmes é legal, a ilegalidade só existindo em sua produção se forem pegos em flagrante.

No Brasil, não existem leis que proíbam diretamente o exercício da sexualidade de humanos com animais. Contudo, existe uma discussão de longa data a respeito da proteção destes últimos. Assim, no marco do debate público sobre a experimentação animal nas ciências biológicas, o decreto n. ${ }^{\circ}$ 24.645, de 10 de julho de 1934, em seu artigo número 3, estabeleceu 31 pautas explicativas sobre o que é considerado mau-trato, entre as quais a primeira foi: praticar ato de abuso ou crueldade em qualquer animal. ${ }^{4}$

4 É possível conhecer o Decreto em sua totalidade no seguinte link: <http://www.forumnacional.com.br/decr_24645_de_10_07_1934.pdf >. É importante 
A Lei Federal no 9.605, do dia 12 de fevereiro de 1998, em seu capítulo 5 (Dos crimes contra o meio ambiente) na Seção 1 (Dos crimes contra a fauna), reafirmou no capítulo 32 a questão da proteção dos animais, proibindo: "praticar ato de abuso, maustratos, ferir ou mutilar animais silvestres, domésticos ou domesticados, nativos ou exóticos", mas tampouco fez referência explícita à sexualidade.

Outra explicação recorrente entre as pessoas que pertencem às redes do pornô em relação à possível ilegalidade dos filmes com animais diz respeito à falta de consentimento do animal para que com ele se pratique sexo. De fato, a noção do não consentimento faz parte do imaginário social, para além do universo do pornô, e aparece recorrentemente no discurso contra o sexo com animais, fazendo alusão ao abuso e à crueldade intrínseca no ato, isto é, submeter, obrigar ou estimular um animal a fazer algo que contradiga sua natureza.

O consentimento como principal critério para definir a licitude de um ato sexual e, em decorrência, como novo modelo de regulação jurídica da sexualidade, tem bases na filosofia do Iluminismo do final do século XVIII (Vigarello, 1998). Centrou-se "nos princípios de livre disposição de si e autonomia da vontade do sujeito racional responsável e senhor de si (...) no ideal individualista moderno" (Lowekron, 2012:35). A noção jurídica do consentimento embasou a criação da categoria violência sexual e a ideia de que esta existe quando se viola o consentimento do sujeito. Esse modelo consensualista da sexualidade ganhou força e expressão política e cultural na segunda metade do século $\mathrm{XX}$ devido às lutas e reivindicações de movimentos sociais especialmente $\mathrm{o}$ movimento feminista $e$ o movimento homossexual, mas também o pensamento da contracultura - por incluir a sexualidade no debate político dos direitos individuais (id.ib.:36). O caso do movimento feminista é emblemático sendo,

perceber que a temática da sexualidade com animais não aparece ao longo do Decreto, nem é incluída dentro das pautas que constituem os maus-tratos. 
Sexo com animais como prática extrema no pornô bizarro

como mostra Lowekron (2008:16) "um dos primeiros movimentos sociais a enfocar o campo jurídico como estratégia política para a promoção de mudanças na desigualdade de gênero". Se já desde os anos 60 tal movimento iniciou uma empreitada a favor dos direitos individuais em relação à sexualidade, foi a partir do final da década de 1980 que "iniciaram uma luta (...) para a inclusão dos crimes sexuais no capítulo 'dos crimes contra a pessoa', demarcando, assim, um espaço discursivo em defesa dos direitos individuais das mulheres" (Vieira, 2007:20, apud Lowekron, 2008:16) e já não mais da honra familiar. ${ }^{5}$

Para além do marco dos crimes sexuais, o consentimento ganha relevância ao ser utilizado como ferramenta de legitimação de práticas sexuais socialmente interpretadas como espúrias. Por exemplo, aquelas associadas ao exercício da violência, como o $B D S M,{ }^{6}$ vêm passando por um processo de validação social empreendido por seus próprios praticantes, a partir do discurso do consentimento, entendido neste contexto como "exercício e expressão da vontade individual em participar de uma atividade sexual [...] principal critério de distinção entre uma forma de sexualidade sadia e a forma patológica" (Zilli, 2007:9). Assim, a partir do consentimento e de regras e rituais para o exercício da atividade, os adeptos do BDSM o legitimam como SSC (são, seguro e consentido), afastando-o dos imaginários da perversão. O BDSM seria, então, um exercício erótico de poder e não um

5 No Código Penal Brasileiro de 1890, as ofensas sexuais estavam enquadradas como "crimes contra a segurança da honra e honestidade das famílias e do ultraje público ao pudor", não sendo consideradas ofensa contra a pessoa (mulher) violentada em si.

6 Acrônimo que engloba uma diversidade de atividades eróticas: "B é para bondage, ou imobilização, geralmente com cordas ou algemas; o par B e D é para bondage e disciplina, o uso de fantasias eróticas de castigos e punições, que se ligam ao par D e S, que representa dominação e submissão. São fantasias de 'entrega' a um parceiro sexual e jogos de representação de humilhação $e$ violação. S e M são as inicias de sadismo e masoquismo, ou de sadomasoquismo - o uso de dor como estímulo erótico. BDSM envolve ainda práticas ligadas ao fetichismo" (Zilli, 2009:481). 
abuso físico ou emocional (Gregori, 2010:168), uma retórica com suas técnicas e rituais que apresenta tensões entre prazer/dor, domínio/sujeição, fantasia/realidade (id.ib.).

O consentimento é também a chave argumentativa para se afastar de rótulos pejorativos utilizada por pessoas que se engajam em práticas de sexo bareback e/ou na ideologia que alguns coletivos têm criado ao seu redor. A palavra barebacking, de origem hípica e que significa "montar a pelo" faz referência atualmente à "prática intencional e contínua, própria de homens que têm relações sexuais com outros homens, de não usar preservativos durante o sexo anal com parceiros casuais" (Haig, 2006:2, apud Garcia, 3009:537). Por se tratar de uma prática intencional e exercida de modo contínuo, dando espaço a formas de contato organizado [...] "o termo alcançou uma conotação que supera o sentido meramente comportamental, tornando-se uma marca identitária, especialmente em certas cidades dos Estados Unidos" (Garcia, 2009:537), como também da Europa.

Se seguirmos o fio argumentativo do consentimento em relação à legitimação de práticas dissidentes, poderíamos dizer que sua ausência, o não consentimento, contribuiria para localizar a zoofilia nos patamares mais baixos da hierarquia sexual. Contudo, se seguirmos esse caminho nos depararemos com uma dificuldade: a noção de consentimento está intimamente ligada à noção de sujeito e, dentro do aparelho jurídico brasileiro, os animais não usufruem desse status.

Como dito anteriormente, o consentimento é o elemento central na definição da licitude de uma relação sexual (Vigarello, 1998) e está diretamente relacionado à categoria de sujeito contemporâneo, isto é, indivíduos com direitos inalienáveis em uma concepção individualista da sociedade (Vianna e Lacerda, 2004). No debate jurídico contemporâneo, a noção de consentimento vincula-se à definição dos direitos de crianças $e$ adolescentes a respeito do exercício de sua sexualidade. As crianças são vistas como sujeitos de direitos, e a violação de seus direitos é percebida como um crime contra a humanidade (Faleiros 
Sexo com animais como prática extrema no pornô bizarro

e Campos, 2000; Lowekron, 2012). Às crianças e adolescentes adjudica-se uma condição de vulnerabilidade, isto é, a ideia de que à diferença das pessoas adultas, eles não possuem maturidade nem psicológica nem física, questão que se aplica para a sua sexualidade. Tendo como principal marco a aprovação da Convenção sobre os Diretos da Criança pela Organização das Nações Unidas (ONU), em 1989, as crianças passaram a ser entendidas como sujeitos de direitos especiais, sujeitos que devem ser tutelados e protegidos pela sociedade, a família e o Estado. ${ }^{7}$

Assim, o sexo com crianças (chamado de abuso ou de pedofilia, com as nuanças e diferenças existentes entre estas noções) e sua exploração ou comercialização no mercado do sexo (redes de prostituição e pornografia) além de ilegais são considerados desprezíveis (ver Landini, 2004), justamente pelo fato de o menor não ser considerado um sujeito que possa administrar o consentimento em nenhuma situação (Lowekron, 2008). Juridicamente, o sexo com crianças é ilegítimo porque viola os

7 Como é explicado no preâmbulo da Convenção sobre os Direitos da Criança: "Considerando que a criança deve estar plenamente preparada para uma vida independente na sociedade e deve ser educada de acordo com os ideais proclamados na Carta das Nações Unidas, especialmente com espírito de paz, dignidade, tolerância, liberdade, igualdade e solidariedade; tendo em conta que a necessidade de proporcionar à criança uma proteção especial foi enunciada na Declaração de Genebra de 1924 sobre os Direitos da Criança e na Declaração dos Direitos da Criança adotada pela Assembleia Geral em 20 de novembro de 1959, e reconhecida na Declaração Universal dos Direitos Humanos, no Pacto Internacional de Direitos Civis e Políticos (em particular nos artigos 23 e 24), no Pacto Internacional de Direitos Econômicos, Sociais e Culturais (em particular no artigo 10) e nos estatutos e instrumentos pertinentes das Agências Especializadas e das organizações internacionais que se interessam pelo bem-estar da criança; tendo em conta que, conforme assinalado na Declaração dos Direitos da Criança, 'a criança, em virtude de sua falta maturidade física e mental, necessita de proteção e cuidados especiais, inclusive a devida proteção legal, tanto antes quanto após seu nascimento"' (grifos meus). 
princípios do consentimento e da igualdade, sendo, em poucas palavras, um crime contra os direitos humanos. ${ }^{8}$

Poderia ser afirmado que os animais são seres que tampouco podem administrar o consentimento em qualquer situação e que, por isso, a sexualidade que lhes envolve é espúria, e sua exploração comercial na pornografia, ilegal. No entanto, como dito anteriormente, este caminho de análise implicaria adjudicar a categoria de sujeito aos animais.

Como transpor a noção de consentimento para falar de animais? Isso nos levaria a repensar a noção do humano e do animal. ${ }^{9}$ Os animais têm alma? Que tipo de alma têm os animais? Que tipo temos nós? ${ }^{10}$ Não vou encarar a discussão por este viés porque precisaria de um arsenal filosófico que se localiza além de minhas buscas intelectuais imediatas. Todavia, já que no pensamento de proteção dos direitos dos animais não se trata de uma questão de alma, o problema recai diretamente sobre o corpo do animal, como é possível perceber nas pautas que estabelecem o que é abuso e crueldade nas leis a eles dirigidas.

8 A penalização jurídica no Brasil para delitos sexuais com crianças é extensa e complexa. Vejamos: Delito de estupro de vulnerável: Art. 217-A do Código Penal (1940) incluído pela Lei $\mathrm{n}^{\circ} 12.015$ de 2009. Delito de corrupção de menores: art. 218 do Código Penal, presente com alterações na Lei n 12.015 de 2009. Delito de satisfação de lascívia mediante presença de criança ou adolescente: art. 218-A, incluído pela Lei $n^{\circ} 12.015$ de 2009. Crime de submeter criança ou adolescente à prostituição ou à exploração sexual: art. 244-A do Estatuto da Criança e do Adolescente - ECA (1990), presente na Lei 9975 de 26 de junho de 2000. O delito de produção e publicação de cenas de sexo explícito ou pornográfico com crianças ou adolescentes foi tipificado pelos artigos 240 e 241 do ECA (1990). Desde então, este vem sendo alterado mediante a inclusão e a definição de novas condutas relacionadas, novos tipos penais e o aumento das penas dos responsáveis. Ver arts. 241-A, 241-B, 241-C, 241-D e 241-E.

9 Ver Ingold, 1995.

${ }^{10}$ Questões que J. M. Coetze coloca em A vida dos animais, por meio de sua personagem principal, Elizabeth Costello, e às quais tampouco traz respostas por serem demasiado filosóficas para seus propósitos, mas que englobam sua discussão sobre os direitos dos animais. 
Sexo com animais como prática extrema no pornô bizarro

O centro da questão é que o ordenamento jurídico nacional não qualifica os animais como sujeitos de direitos. Isto porque, segundo tal ordenamento, a existência do sujeito de direito pressupõe a personalidade, ou seja, é preciso ser pessoa ou nascituro. Pessoa é o ser humano que nasce com vida, no caso, a "pessoa física". É próprio das pessoas possuírem direitos e obrigações. Mas isto também serve para o "nascituro", ou seja, o feto. O feto não é pessoa no sentido de que ainda não é nascido, mas detém expectativas de direito e deveres: o feto pode ter direito à herança, por exemplo. ${ }^{11}$ Os animais, por sua vez, são tutelados pelo ordenamento jurídico nacional, ${ }^{12}$ mas existe uma diferença entre ser tutelado e ser sujeito (especialmente se levarmos em conta que, no artigo 9.605 de 1998, os animais fazem parte do "meio ambiente" - dividido entre fauna e flora - e um crime contra eles é considerado um crime ambiental). $\mathrm{O}$ fato de as crianças, por exemplo, também serem tuteladas não significa que sejam equiparáveis juridicamente aos animais. Mesmo existindo normas internacionais, como a Declaração Universal dos Direitos dos Animais, em que são utilizadas expressões como "os animais têm direitos a", isso não os configura como sujeitos de direitos. ${ }^{13}$

${ }^{11}$ Agradeço Roberto Efrem pelos esclarecimentos a este respeito. Ver a Lei de Introdução ao Código Civil Brasileiro. Art. 1: "Toda pessoa é capaz de direitos e deveres na ordem civil". Art. 2: "A personalidade civil da pessoa começa do nascimento com vida; mas a lei põe a salvo, desde a concepção, os direitos do nascituro".

12 No Brasil, a proteção da fauna vem sendo garantida por diversos instrumentos legislativos (Código de Caça, Código de Pesca, Lei de Contravenções Penais) e, a partir de 1988, a tutela jurídica dos animais passou a ter status constitucional (Calhau, 2003).

${ }^{13}$ A antropóloga Mayra Vergotti (2011:6) explica: "Assim, o uso do termo 'direito' se torna uma ferramenta para os ativistas, quando percebem que não existe uma proximidade afetiva (alguns vegetarianos chamam de 'empatia') largamente difundida". Para ativistas, explica a autora, respeito e ética devem ser moralmente garantidos. "Existe hoje o termo 'ética animalista', que se refere a uma empreitada de filósofos contemporâneos (e também de psicólogos, advogados e outros intelectuais), que estão construindo uma base filosófica, na qual os animais são incluídos formalmente em nossa moralidade". 
Acredito estarmos diante de um dilema de interpretação. $\mathrm{O}$ Estado brasileiro penaliza a crueldade e o abuso contra os animais, como já mencionado, mas a sexualidade que os envolve pode ser considerada um abuso ou uma crueldade? A resposta para esta pergunta precisa de um longo debate. As legislações já existentes até poderiam englobar o sexo com animais como violência. Mas englobar é diferente de configurar de fato uma violência. ${ }^{14} \mathrm{E}$ mesmo que pudesse configurar uma violência, seria necessário diferenciar violência de crime. A ausência total da menção à sexualidade como abuso na atual legislação brasileira permite brechas, e são justamente essas brechas que tornam possiveis a produção $e$ a comercialização não clandestina de filmes de sexo com animais. Essa pornografia fere leis, certamente. Mas trata-se de leis simbólicas e morais, e não necessariamente jurídicas.

Acredito que a condenação moral desse material não se deve exclusivamente ao fato de ser consentido ou não. Não creio que seja a nebulosidade em torno de sua licitude o principal critério para torná-lo moralmente condenável. Não é sua legalidade ambígua o que faz com que muitos de nós fechemos os olhos quando nos deparamos com uma imagem em que uma mulher é penetrada por um cavalo ou uma serpente. É outra coisa o que causa nojo em muitos de nós. O sexo com animais é difamado, acredito, porque desperta a sensação de monstruosidade, porque choca os fios mais íntimos de nossa sensibilidade, porque apela ao perverso, ao irracional, enfim, ao monstruoso.

\section{Animais humanizados, humanos bestializados}

A bibliografia antropológica que trata das relações entre humanos e animais é extensa (por exemplo, Leach, 1983; Viveiros de Castro, 1986; Lima, 1999; Descola, 1998; Vander Velden, 2010). Nesse bojo, um amplo campo de estudos vem analisando a existência, em nossas sociedades urbanas contemporâneas, de diversas

${ }^{14}$ Agradeço Guilherme Antunes pelos esclarecimentos a esse respeito. 
Sexo com animais como prática extrema no pornô bizarro

experiências sociais nas quais são borradas as fronteiras entre as espécies: a obesidade animal como problemática social que demanda intervenção (Kulick, 2009), a domesticidade canina (Haraway, 2008; Antunes, 2011), hábitos e tabus alimentares (Sahlins, 2003) somados a afetos e a éticas classificatórias (Vergotti, 2011), ou rituais urbanos como festas de aniversário canino e cerimônias religiosas de benção aos animais (Brasil, 2006). Esses textos chamam a atenção para processos de humanização dos animais na interação íntima com indivíduos em contextos domésticos, pela via do afeto e da emoção - antropomorfização é uma noção utilizada em alguns desses estudos em relação às características humanas adjudicadas aos animais - e para como os animais contribuiriam para humanizar os humanos. Sem dúvida, as fronteiras entre humanos $e$ animais ( $e$, de fato, entre natureza $e$ cultura) tornam-se tênues em experiências como a adoção de filhotes e seu tratamento como crianças, ou quando milionários deixam enormes heranças para suas mascotes, ou ainda no vasto mercado existente em torno de produtos e práticas de embelezamento para cachorros e gatos.

Nota-se que enquanto os afetos operam borramentos das fronteiras entre as espécies, a sexualidade constitui um plano no qual tais fronteiras são espessas e impenetráveis, configurando-se como um limite do social. No entanto, a noção de humanização dos animais aparece no pornô. Contudo, neste dispositivo, eles não contribuiriam para humanizar os humanos. Ao contrário, projeta-se a ideia de que através do contato sexual o humano se bestializa.

Dentre os signos agenciados imageticamente pela pornografia visando representar a cópula entre humanos $e$ animais, encontramos uma tensão permanente. Há nessas imagens um esforço em mostrar que se trata de uma prática transgressora, que é vendida como perversa. Simultaneamente, há um esforço em demonstrar que, de alguma forma, ela pode ser corriqueira. $\mathrm{O}$ animal assume ali uma dupla personalidade: pode ser monstruoso, absurdo, imundo e, ao mesmo tempo, fiel, amigável, quase humano. Não são poucos os enunciados que 
parecem humanizar o animal, ao demonstrar ser ele um ser próximo da pessoa, que existe entre eles um afeto e uma relação prévios, por serem, por exemplo, o dono e seu bicho de estimação. Vale a pena esclarecer que esse tipo de enunciado é utilizado especificamente nas legendas que acompanham as fotografias de promoção do filme, seja em vídeos ou na Internet - levando-se em conta que o pornô atual está majoritariamente voltado para essa mídia e que se trata de cenas carentes de enredo - uma vez que, na transa como tal, tal enunciado desaparece.

No pornô internacional, dentre os animais utilizados, encontram-se porcos, galinhas, cabras, polvos, serpentes, insetos e minhocas. Cachorros e cavalos são, no entanto, os mais comuns. No pornô produzido no Brasil são usados quase que exclusivamente cavalos, cachorros e burros, com a predominância dos dois primeiros. Acredito que os discursos construídos acerca da humanização dos animais só são possíveis por se tratarem de cães e equinos, ambos integrados às nossas sociedades com status de "não comestíveis", uma vez que "a comestibilidade está inversamente relacionada com a humanidade" (Sahlins, 2003:175) e porque

as manifestações de simpatia pelos animais são ordenadas em uma escala de valor (...) cujo ápice é ocupado pelas espécies percebidas como as mais próximas do homem em função de seu comportamento, fisiologia, faculdades cognitivas ou da capacidade que lhes é atribuída de sentir emoções (Descola, 1998:23). ${ }^{15}$

${ }^{15}$ Em um artigo sobre as práticas de sexo entre indígenas karitiana e cadelas, o antropólogo Felipe Vander Velden (2010: 7) escreve: "Arrisco-me a sugerir que a conjunção carnal com cães, por mais excêntrica que pareça, é plenamente aceitável - ainda que ridicularizada - sob a ótica karitiana porque o cachorro doméstico não está fora do universo humanizado; ele é parte integral desse mundo socializado ou, melhor dizendo, o cachorro é a própria dobradiça entre o mundo não humano, predatório e perigoso do mato, e o contexto familiar, seguro e organizado da aldeia". 
Sexo com animais como prática extrema no pornô bizarro

Camila e seu cão são melhores amigos. Ambos amam sexo bizarro e juntos experimentam as mais selvagens aventuras. Camila dá ao seu bichinho um boquete legal e depois disso, seu cão quer enfiar seu nó em sua buceta molhada. Ela grita loucamente quando atinge um clímax combinado com dor e prazer extremos.

A legenda anterior é só uma entre outras tantas que ostentam essa característica. Elas explicitam o discurso sobre o espetacular e o excesso que atravessa a ideologia pornográfica no geral, motivo pelo qual utiliza uma linguagem que convida o espectador a assistir a algo especial, estranho e fora do cotidiano: não simplesmente sexo, mas proezas sexuais; não somente corpos, mas corpos incriveis ou "grotescos"; não somente genitálias, mas seus tamanhos e capacidades extremas. Do mesmo modo como na pornografia hetero o pênis dos homens é central nas imagens, no pornô com animais, o genital do macho, especialmente quando se trata de um cavalo, tem grande destaque. Ele é enfocado de todos os ângulos possíveis. Sua dimensão, sua cor, sua umidade, sua ejaculação, tudo precisa integrar um espetáculo de prazeres exagerados, sendo esse o limite da humanização - ali o animal recobra sua característica animal, tornando-se novamente uma besta.

$\mathrm{O}$ pornô brasileiro com animais se vale preferencialmente de cinco tipos de pessoas: mulheres jovens e bonitas, às vezes, quase ninfetas; senhoras mais velhas que, na pornografia, são conhecidas como milf; ${ }^{16}$ mulheres gordas ou próximas da obesidade; mulheres geralmente jovens com atributos físicos não necessariamente considerados belos - em alguns sites sendo classificadas como mulheres pobres $-e$ travestis.

\footnotetext{
${ }^{16} \mathrm{O}$ acrônimo MILF, do inglês Mom I'd Like to Fuck (traduz-se, na maior parte da hispano-américa como MQMC, Mamá Que Me Cogería. Na Espanha como MQMF, Madre Que Me Follaría, faz referência às mulheres que em uma idade relativamente avançada (na pornografia, de 30 a 50 anos) são atrativas e sexualmente desejáveis (Fonte: Wikipedia).
} 
Os diversos enunciados, e entre eles a humanização, vão aparecendo e se interpenetrando de modo contingente. Um momento no qual o animal é particularmente humanizado consiste naquele em que se enfatiza que ele, diferentemente dos homens, não se interessa pelo fato de a mulher possuir um visual desleixado, podendo suprir os problemas de solidão ou de excitação que ela possa apresentar. Isto é comum em filmes com mulheres gordas (ou BBW - Big Beautiful Women - como são conhecidas no mercado internacional), com milfs ou com outras mulheres de idade avançada que não se encaixariam na categoria milfs por não serem consideradas fisicamente atraentes.

Nadia está solteira há dois anos e ela pensa que a maioria dos homens simplesmente não gosta de BBW como ela. Para que possa ter algum sexo nestes tempos difíceis, um amigo sugere-lhe que faça sexo com cães. O cão não se importa com seu corpo gordo... Ele apenas quer enfiar seu duro nó canino em sua buceta! Quentíssima ação animal com BBW que você realmente tem que ver!

Esta safada dona de casa encontrou a solução perfeita para seus problemas sexuais. A maioria dos homens não se interessa mais por ela, mas seu fiel animal de estimação não é tão exigente. Confira este grande filme de sexo bestial $e$ veja como esta loira milf é fodida extremamente forte por seu próprio cão... em estilo canino!

Aqui prevalece a ideia de que ninguém deseja fazer sexo com elas, e o animal - amigo, camarada, fiel - é uma alternativa aos seus problemas, causados por seus corpos esteticamente não aceitos. Ao mesmo tempo, lê-se que o animal, justamente por ser um animal - irracional, preso a seus instintos, como os monstros concebe o sexo "extremamente forte" com esses corpos igualmente bizarros por excelência.

Outro enunciado presente nessas narrativas é a ideia de que o sexo com animais é produto da solidão. Este é, na verdade, um 
Sexo com animais como prática extrema no pornô bizarro

velho discurso. Não raro no imaginário social, a zoofilia é interpretada como resultado do isolamento, da ausência de parceiro e da dificuldade nas relações sociais. ${ }^{17}$ Temos aqui um retorno ao discurso da sexologia: quem transa com animais não é necessariamente perverso, é um infeliz, um doente, um coitado.

Igualmente, é comum encontrarmos cenas em que duas mulheres - às vezes milfs, às vezes jovens - fazem sexo entre si $e$ com o animal. Trata-se de ménages à trois que parecem seguir o esquema enunciativo dos filmes pornô mainstream que contemplam esse arranjo.

Estas milfs brasileiras gostam de sentir um pinto de verdade em suas bucetas de vez em quando. Já que elas não amam homens, elas decidiram experimentar sexo com cães! Entre aqui para filmes lésbicos de sexo bestial únicos e veja estas mulheres maduras sendo brutalmente fodidas por animais.

Duas lésbicas gostosas curtindo uma zoofilia com um cavalo. As duas safadas se chupam, se beijam e aproveitam a pica do cavalo para curtir uma putaria e acabar com o tesão.

Aqui me parece ser estabelecida uma relação entre desvios: pelo fato de serem lésbicas, isto é, portadoras de um desejo que extrapola a norma, elas estariam predispostas a experimentar outro desejo periférico: transar com animais. Todavia, fica

${ }^{17}$ No caso do Brasil, ela também costuma ser associada a comportamentos tradicionais (selvagens e incompreensíveis) levados a cabo em sociedades rurais por "caipiras", e/ou por pessoas carentes de uma educação formal. Delimita-se assim que aquilo acontece lá, no campo, onde a civilização pouco chegou, a ponto de se conceber que, nesses contextos, se trate de um comportamento até mesmo esperado, sendo comum por exemplo, como uma prática de iniciação sexual para rapazes. A questão é que nas narrativas da tradição popular, são homens que transam com animais fêmeas, sendo o contrário - mulheres transando com animais machos - concebido como contravenção. É justamente essa contravenção social que surge nos filmes aqui descritos. 
enunciada a ideia de que o sexo entre mulheres é algo de algum modo inacabado, e que é preciso um falo "de verdade" para tirálas de um jogo de sedução incompleto.

Por outro lado, a opinião generalizada entre as redes do pornô (mas também no imaginário social) de que as pessoas transam com animais como resposta a necessidades econômicas extremas, também aparece em legendas usadas em alguns sites estrangeiros para divulgação das mulheres:

Elenco "animal", cenas de sexo animal e filmes de bestialidade brutal: garotas amadoras fodendo animais por dinheiro! Durante nossas viagens sexuais, oferecemos 150 dólares a pobres piranhas em troca de sexo com animais. Estas mulheres estrangeiras realmente fazem tudo por dinheiro!

Outra pobre piranha brasileira que se sujeitou ao nosso elenco animal para poder pagar dívidas.

Jovem adolescente que se tornou uma modelo animal no ano passado, quando foi despedida de seu trabalho. Corpo sexy incrível!

Esta puta caipira apenas queria ganhar algum dinheiro extra para poder pagar seu aluguel.

Experiente piranha "animal" que não tem nenhuma vergonha. Se você dá dinheiro, ela se torna sua escrava pessoal.

Projeta-se assim a ideia de que a linha que separa a pobreza do desvio é demasiado tênue, que um pobre faz de tudo para pagar suas contas, até mesmo sexo com animais. Mas, neste caso, não se trata somente de mulheres pobres, e sim de prostitutas pobres. Ou seja, mulheres cujas condutas sexuais já se localizam na ordem da transgressão estariam mais próximas do exercício de práticas sexuais extremas. 
Sexo com animais como prática extrema no pornô bizarro

Desse modo, corpos e sexualidades brasileiras são enquadrados a partir de um olhar externo e etnocentrista, expressando concepções estereotipadas de raça, classe, nacionalidade e gênero. Nesses discursos, as nativas são pensadas como essencialmente sexualizadas e exóticas. Contudo, trata-se de um exotismo perigoso, capaz de fomentar a ilusão de admiração pelo outro e, paralelamente, se construir sobre relações de desigualdade (Kempadoo, 2000). Nessas legendas, a pobreza, a nacionalidade e o gênero são vendidos como algo prodigioso $e$ simultaneamente esdrúxulo.

Finalmente, entre o conjunto das mulheres, o enunciado que menciona prazeres e desejos - e, dessa vez não com um animal humanizado, mas justamente com uma besta - é mais recorrente quando se trata de mulheres jovens e bonitas. Vejamos dois exemplos:

Quando Priscilla confortavelmente toma um banho de sol em seu luxuoso jardim, sua amiga se aproxima com seu novo cão. Sem nenhuma vergonha, ela pergunta a Priscilla se ela quer dar ao seu animal seu primeiro orgasmo verdadeiro. Priscilla acha que é uma grande honra e, sem perder tempo, tem seu úmido nó canino profundamente alojado em sua estreita boca. É isso aí garota!

Estas garotas estão cansadas de todos aqueles homens tarados, então elas decidem procurar uma nova maneira de satisfazer suas necessidades. Elas escolhem experimentar sexo animal e parece que esta foi uma boa escolha. Nós todos sabemos que os cães podem lamber extremamente bem, mas estas mulheres encontraram uma maneira de usar isso para seu proveito. Ouça-as gritarem ainda mais enquanto atingem seu segundo orgasmo em uma hora.

Assistimos aí a um desejo de transgressão: por que mulheres com atributos físicos desejáveis se engajam prazerosamente em sexo com animais? Por que justamente elas, que não precisam 
recorrer a essa solução, já que poderiam captar a atenção de qualquer homem? Porque elas gostam, respondem-nos. Inserir corpos jovens e belos nessas práticas poderia insinuar-se como mais chocante. Espera-se (e até aceita-se) que sejam corpos "espúrios" aqueles que aderem a esse tipo de sexo. Por essa razão, o pornô bizarro está repleto de corpos deslegitimados: anões, obesos, idosos, deficientes, decepados etc., mas a presença dos corpos "legítimos" incomoda, revela-se incompreensível, mexe com nossas categorias. Também, obviamente, isto se dá em função das demandas do mercado: quem consome, em sua maioria, deseja ver lindas garotas, pois também nesse segmento do mercado pornô a beleza da mulher constitui um capital simbólico e uma ponta de lança da indústria.

Por último, no mercado de filmes de travestis com animais é possível observar enunciados como os seguintes:

Quentíssima travesti brasileira chupando um cavalo. Quando o animal está pronto para um orgasmo, a transexual se curva para que o animal possa colocar sua porra em seu cu imundo.

Um grupo de transexuais brasileiras extremamente quentes dançando com seus biquínis na fazenda. Elas estão completamente fascinadas pelo massivo pau equino $e$ querem rápido este pinto grande em suas bucetas masculinas.

Por um lado, salta aos olhos a utilização de expressões pejorativas nas quais se misturam o desejo e o repúdio. São "cus imundos" porque pertencem a travestis, seus corpos sendo anunciados como ilegítimos - no sentido de sujos, raros $e$ indecentes - e simultaneamente excitantes. ${ }^{18}$ Nessa mesma ordem

\footnotetext{
${ }^{18}$ Essas dicotomias ultrapassariam a percepção de seus corpos. Em sua etnografia, Don Kulick (2008) argumentou que, em relação às travestis, grande parte da população nacional divide-se sentimentalmente entre o amor e o ódio. Do mesmo modo como, nos anos 1980, Roberta Close ascendeu à categoria de
} 
Sexo com animais como prática extrema no pornô bizarro

de ideias, situaria-se a ambiguidade de seus corpos, por meio de expressões como "bucetas masculinas". Já dissera Jorge Leite Jr. (2006b:2) que, para as produções pornôs, esse corpo "se inscreve em outro território do desejo", um desejo que percebem como raro, reforçando a ideia de que o sexo com elas é incomum, "anormal" e, justamente por essas razões, fantástico. A indústria pornô explora o fato de que o corpo travesti subverte as dicotomias ao não se ajustar às alternativas homem/mulher $e$ masculino/feminino e, nessa exploração, o humor é utilizado como um signo-chave da representação do grotesco.

Vale a pena esclarecer que os produtores de pornô não se sentem necessariamente compelidos a procurar $e$ incluir nas filmagens esse tipo específico de pessoas (com exceção das travestis $e$ das mulheres jovens e bonitas que são enfaticamente procuradas). $\mathrm{Na}$ realidade, as coisas são mais bagunçadas: no processo de recrutamento do elenco, eles "jogam a rede" $e$ acabam filmando com quem conseguirem captar, nem sempre conseguindo recrutar as mulheres mais cotadas do mercado do sexo. Em outras palavras, eles gravam com o que "tiverem à mão" $e$, uma vez o filme pronto, inventam legendas de acordo com os corpos e aparências das atrizes, ou então vendem as cenas soltas e são os produtores estrangeiros que se encarregam de fazê-lo. É por essa mesma razão que o mercado de sexo com animais é tão estigmatizado dentro das próprias redes do pornô, pelo tipo de pessoas que inclui: humanos que, por suas fisionomias e pelo exercício dessas práticas, se tornam (e são percebidos como) menos humanos.

As visões presentes nesses enunciados parecem evidenciar que se trata de uma indústria feita por homens para homens (por vezes

diva, sendo consagrada e admirada por multidões, a sociedade promove cotidianamente manifestações de discriminação e até violência física contra estes indivíduos. "As pessoas não conseguem definir o que seria uma travesti. Essa dificuldade em localizá-las em uma definição segura de gênero e orientação sexual as faz fascinantes e perigosas, sedutoras e poluidoras, com sensível predominância dos segundos termos dessas díades" (Pelúcio, 2008:6). 
homens nacionais para homens estrangeiros, por outras homens estrangeiros para outros estrangeiros) e que essa pornografia, como muitas outras, parece transgredir normas de cunho sexual, especialmente por penetrar no terreno das "perversões", enquanto simultaneamente conserva vigentes convenções estereotipantes sobre outros marcadores sociais da diferença.

\section{Sexo com animais e os limites da sexualidade}

Não é apenas terror que a figura monstruosa provoca. É também fascínio, encanto, dúvida, fonte de curiosidade e desejo (Leite, 2006a:180).

O monstro é transgressivo, demasiadamente sexual, perversamente erótico, um fora-da-lei (Cohen, 2000:48 apud Leite, ibid, 180).

Quando indago consumidores de filmes de sexo com animais a respeito de seu prazer, um deles menciona um filme japonês em que uma mulher se acariciava com os tentáculos de um polvo e lentamente os introduzia no ânus e na vagina. "A mulher era belíssima - comenta - ela nua era linda, era impossivel não me excitar, mas, ao mesmo tempo, a cena toda era muito nojenta".

Essa é uma das respostas mais comuns que tenho escutado em meu trabalho de campo. Uma mistura de desejo e asco embutido nos dispositivos de prazer do pornô com animais. Esse é o efeito que causa porque, como estética, une o belo e o feio, o limpo e o sujo, o próximo e o distante. No entanto, entre outros indivíduos que desfrutam desses materiais, a sensação de asco não seria um fato marcante. Para eles, o animal simboliza o grande, o sublime, aquilo que está além. Um diretor de pornô com animais me diz a este respeito:

O filme que mais me excita fazer é de cavalo. Me dá muito tesão, não sei te explicar. Eu sinto que a mulher está gostando. Eu estou vendo, sabe? Eu vejo que a mulher está sentindo prazer, então, de ver a mulher sentindo prazer, me 
dá prazer. Você vê que a buceta dela fica inchada e toda molhada, que a pele dela fica arrepiada, o bico do peito fica duro. O pau do cavalo é como um braço de grosso, $e$ quando as meninas enfiam, elas fecham os olhos $e$ esquecem tudo. Eu já vi várias delas gozar. É demais! Eu fico com tesão só de lembrar.

De ambos os pontos de vista, a união de espécies diferentes é transcendente nesse paradigma, sendo isto o que verdadeiramente estimula. ${ }^{19}$ Assim, o pornô com animais não estaria lidando necessariamente com uma "sensibilidade zoófila", pois o animal pareceria não seduzir por si só. O humano precisa estar presente para que o desejo seja detonado entre os consumidores desse material.

$\mathrm{O}$ fato de que o humano presente nesses filmes seja (quase) exclusivamente feminino nos permitiria pensar que o que se movimenta ali é uma "sensibilidade hetero-compulsória", para usar os termos de Gayle Rubin. Hetero-compulsória mesmo interespécies, se é que podemos chamar assim. Desperta o prazer assistir uma mulher sendo penetrada por um cavalo e, como dito anteriormente, a importância do pênis, nesses casos, é enorme. Trata-se de um animal com uma genitália abissal e de mulheres sendo "fodidas" de forma bestial como no pornô hetero mais hard. Desde as longas sequências de sexo oral até a ejaculação do animal, as imagens constroem um ideal de masculinidade associado à potência. $\mathrm{O}$ estilo da transa não diferiria muito das séries "violação e massacre anal" produzidas por empresas do pornô hetero nacional. Trata-se novamente de um pênis másculo e gigante - mais gigante ainda - satisfazendo uma mulher. $\mathrm{Na}$ enunciação desses prazeres, somente a penetração não é suficiente, sendo imprescindível um estilo veemente e voraz. A única diferença é, que nessas práticas, é a mulher que conduz a

${ }^{19}$ Minha hipótese é a de que, talvez, quem queira procurar excitação basicamente no animal busque assistir sexo entre animais, filmes estes facilmente encontrados na Internet. 
cena, quem toma a genitália do animal em suas mãos e a introduz em si mesma com grande ritmo e força. Em meio a essa sensibilidade hetero-compulsória levantada pelas produções, torna-se importante o modo como a mulher demonstra com gestos e palavras o quanto a penetração é prazerosa.

Em sua maioria, os filmes de sexo com animais não costumam trazer à tona discursos sobre a dor. Mesmo quando se trata do pênis de um cavalo e de penetrações anais, a representação da dor é deixada de lado.

Isso é contrário às convenções do pornô mainstream, no qual a dor é algumas vezes tão efetiva quanto o prazer, no momento de se representar especificamente as sexualidades femininas, ou a sexualidade daqueles que exercem o papel receptor na cópula. Acredito que a negação da dor nos filmes de pornô com animais seja um mecanismo de criar convenções que evidenciem que se trata de uma prática, de algum modo, confiável. Essa seria uma forma de legitimá-la. ${ }^{20}$ Nessa demonstração de prazer extremo, são utilizados alguns signos como tensores: o sangue é um deles. Em alguns desses filmes, as mulheres sangram, mas ao contrário do que se poderia esperar (levando-se em conta que se procura negar a dor), nesses casos os produtores não tentam esconder tal fato. Assim, o fluido aparece nas cenas, sendo captado de perto pelas câmeras, ganhando destaque na imagem $e$ nas fotografias que serão usadas para a divulgação do filme. Se nos bastidores de filmagem do pornô hetero, o surgimento de um excremento ou de um fluido (com exceção do sêmen e da saliva) é tomado como um acidente da performance - que deve ser camuflado com truques de edição ou pausando a filmagem para limpar os corpos e o cenário - no pornô com animais, o sangue é um enunciado performativo chave

\footnotetext{
${ }^{20}$ Isso nos faz lembrar The Catacombs (Rubin, 2001), um clube de sexo aberto nos anos 70, em São Francisco, voltado para o S/M, no qual eram tomados diversos cuidados, como o teste de objetos e técnicas, para garantir o prazer dos corpos em meio a uma experiência sexual radical. Ali, até mesmo certas modalidades de dor eram estudadas e convencionadas (Gregori, 2010).
} 
Sexo com animais como prática extrema no pornô bizarro

na demonstração de desejos e prazeres. O sangue é uma demonstração do excesso e simultaneamente do realismo, ambos os signos sendo reivindicados pela pornografia. $\mathrm{O}$ sangue demonstra que a pele tocou seus limites, que o prazer e o perigo se tornaram carne. É assim que o pornô com animais se inscreveria dentro daquilo que Gregori (2010:3) caracterizou como limites da sexualidade, isto é, "a zona fronteiriça onde habitam norma e transgressão, consentimento e abuso, prazer e dor".

$\mathrm{Na}$ verdade, o pornô com animais é um mercado que coloca em disputa diversos limites: morais, éticos, sexuais, e em última instância, sanitários, este último na medida em que todo sexo feito sem proteção, e certamente em se tratando de animais, coloca para seus praticantes a questão do risco de contágio de doenças sexualmente transmissíveis. Há ali estabelecida outra tensão: para algumas pessoas do meio pesquisado, os cachorros são considerados mal cheirosos, sujos, especialmente pelas quantidades de saliva que produzem espontaneamente. Há quem acredite nesse universo que os cães são portadores de gonorreia desde o nascimento. Sendo assim, vemos que, por um lado, os cachorros possibilitam o surgimento de discursos de humanização por se tratarem de animais próximos e conhecidos. Mas por outro lado, também é possível pensar que justamente por serem vistos como sujos são os eleitos para transar com mulheres e travestis, $e$ talvez isso tenha a ver com o paradigma da humilhação, tão caro à pornografia do fetiche. ${ }^{21}$

\footnotetext{
${ }^{21}$ Esta é uma hipótese a ser desenvolvida. Há um enorme leque de fetiches no pornô baseado na dupla escravo/dominador - no qual se destacam diversos tipos de sufocações, engasgamentos, pisadas, batidas etc. - que não deve ser confundido com as práticas $\mathrm{S} / \mathrm{M}$ nem com a ideologia a seu redor. Tampouco se trata da humilhação como entenderam Catharine Mackinnon e Andrea Dworkin na criação das bases do feminismo conhecido como radical, não somente porque nestes fetiches quando se trata de duplas homem/mulher, geralmente, são as mulheres as dominadoras, mas também porque está sujeito a paródias, transgressões e negociações de sentido, de modo algum simbolizando a degradação feminina de modo literal.
} 
Para finalizar, desejo enfatizar o quanto a pornografia tem necessidade de brincar com a alteridade. Daí, os inúmeros segmentos do mercado $e$ as múltiplas subdivisões que vão aparecendo em uma dinâmica que parece nunca acabar. Nesse jogo de criatividade na representação da alteridade, a pornografia busca superar-se a si mesma. O emergente mercado de sexo com alienígenas é um exemplo desta questão: se, no pornô, os animais podem representar nossos monstros e gerar discursos de monstruosidade, o pornô com alienígenas leva essa ideia ao paroxismo, ao colocar humanos (novamente mulheres em sua maioria) fazendo sexo com seres "radicalmente desconhecidos", verdadeiros forasteiros cujos corpos (com todas as suas antenas, escamas e formas híbridas entre répteis, anfíbios $e$ aves) representam os limites da monstruosidade, e assim, os limites de uma sexualidade monstruosa. No entanto, algo precisa ser dito. $\mathrm{O}$ pornô com "nojentos alienígenas" desperta o asco, sem dúvida, mas também dá espaços para o riso. Justamente porque quem assiste a esses filmes sabe que se trata de uma montagem ou de um humano fantasiado de alien (por mais horrorosa que seja a fantasia), havendo assim um simulacro de corporalidade extraterrestre, na qual o riso é possível na parodia ao grotesco. $\mathrm{O}$ mesmo não ocorre com os animais, essas performances raramente sendo recebidas com humor.

O que é despertado pelo pornô com animais são metáforas de horror, não porque seja simplesmente "nojento", mas porque permanece nos limites da sexualidade com todas as suas dicotomias: prazer, dor, abuso, animal humanizado, animal que é besta, humano que, na procura desses prazeres, se animaliza.

O horror advém da desconexão entre o corpo humano e o corpo animal, da possibilidade de se aceitar que talvez possam se comunicar e ter prazer. Estabelece-se aí uma tensão, uma vez que se trata de corpos distintos cujas barreiras, em matéria de sexualidade espera-se que sejam intransponíveis. O horror advém da probabilidade de conceber o corpo do animal como desejável. Porque desejá-lo talvez signifique humanizá-lo, ou pior ainda, 
Sexo com animais como prática extrema no pornô bizarro

porque não humanizá-lo possa se traduzir na aceitação do desvio, de que o que se deseja mesmo é uma besta.

\section{Referências bibliográficas}

ANTUNES, Guilherme. Sobre pets e 'párias': pensando natureza e sociedade através de ontologias caninas. In: Memórias das Jornadas de Antropologia da Unicamp. 2011. Disponível em: $<\mathrm{http}$ ://antropologias.descentro.org/seminarioppgas/>

BECKER, Howard. Los extraños: sociología de la desviación. Buenos Aires, Tiempo contemporâneo, 1971 [1963].

BRASIL, Samantha da Silva. Festa boa pra cachorro: relações entre humanos e não-humanos no ambiente urbano. In: Memórias da $26^{a}$ Reunião Brasileira de Antropologia, 2006.

CALHAU, Lélio Braga. Meio ambiente e tutela penal nos maus-tratos contra animais. Revista Jus Navigandi. Disponível em: $<$ http://jus.com.br/revista/texto/5585/meio-ambiente-e-tutela-penalnos-maus-tratos-contra-animais/2>

COETZE, J.M. A vida dos animais. São Paulo, Companhia das Letras, 2003.

DeKKERS, Midas. Dearest Pet. On bestiality. London, New York, Verso, 1992.

DESCOLA, Philippe. Estrutura ou sentimento: A relação com o animal na Amazônia. Mana, vol. 1, nº 4, São Paulo, 1998, pp.23-45.

DiAZ-BENITEZ, María Elvira. Nas Redes do sexo: os bastidores do pornô brasileiro. Rio de Janeiro, Zahar Editores, 2010.

Douglas, Mary. Pureza y Peligro: un análisis de los conceptos polución y tabú. Madrid, Siglo XXI, 1991.

FAlEIROS, Silveria Eva T.; CAMPOS, Josete de Oliveira. Repensando os conceitos de violência, abuso e exploração sexual de crianças e de adolescentes. Brasília, Cecria/MJ-SEDH-DCA/FBB/Unicef, 2000.

FouCAUlt, Michel. Historia de la Sexualidad. La Voluntad del saber, vol. 1. México, Siglo Veintiuno, 1991 [1976].

GARCIA, Esteban. Políticas e prazeres dos fluidos masculinos: barebacking, esportes de risco e terrorismo biológico. In: DíAz-- 
Benítez, Maria Elvira e FíGARI, Carlos. Prazeres Dissidentes. Rio de Janeiro, Editora Garamond, 2009, pp.537-566.

GREGORI, Maria Filomena Prazeres perigosos: erotismo, gênero e limites da sexualidade. Tese de livre docência, Departamento de Antropologia, IFCH, Universidade Estadual de Campinas, 2010.

. Prazer e Perigo: Notas sobre feminismo, Sex-Shops e S/M. In: PISCITElli, Adriana, GREGORI, Maria Filomena e CARRARA, Sergio. (orgs) Sexualidades e saberes: Convenções e fronteiras. Rio de Janeiro, Editora Garamond, 2004, pp.235-256.

. Relações entre violência e erotismo. Cadernos Pagu (20), Campinas-SP, Núcleo de Estudos de Gênero-Pagu/Unicamp, 2003, pp.87-120.

HARAWAY, Donna. When Species Meet. Minneapolis, University of Minnesota Press, 2008.

INGOLD, Tim. Humanidade e animalidade. Revista Brasileira de Ciências Sociais n 28, São Paulo, junho 1995, pp.1-15.

KAYSER, Wolfgang. O grotesco. São Paulo, Perspectiva, 1986.

KEMPADOO, Kemala. Gender, race and sex: exoticism in the Caribbean. Paper apresentado no Simpósio internacional $O$ desafio da diferença: articulando gênero, raça e classe, realizado em Salvador-BA, 2000.

KuliCK, Don. Animais gordos e a dissolução da fronteira entre as espécies. Revista Mana, 15 (2), Rio de Janeiro, 2009, pp.481-508.

. Travesti: prostituição, sexo, gênero e cultura no Brasil. Rio de Janeiro, Editora Fiocruz, 2008.

LANDINI, Tatiana. Pedofilia e Pornografia Infantil: algumas notas. In: Piscitelli, Adriana, GREGORI, Maria Filomena e CARRARA, Sergio. (orgs.) Sexualidades e saberes: Convenções e fronteiras. Rio de Janeiro, Garamond Universitária, 2004, pp.319-344.

LEACH, Edmund. Aspectos antropológicos da linguagem: categorias animais $e$ insultos verbais. In: DAMATTA, Roberto. Edmund Leach: Antropologia. São Paulo, Ática, 1983. 
Sexo com animais como prática extrema no pornô bizarro

LEITE, Jorge. Das maravilhas e prodígios sexuais. A pornografia bizarra como entretenimento. São Paulo, Fapesp/Annablume, 2006a.

. O melhor de dois mundos. Sexualidade, entretenimento e pornografia com travestis. Anais do Encontro Internaconal Fazendo Gênero 7, Universidade Federal de Santa Catarina, 2006b.

LIMA, Tânia Stolze. Para uma teoria etnográfica da distinçao entre natureza e cultura na cosmologia Juruna. Revista Brasileira de Ciências Sociais, vol. 14 n 40, São Paulo, junho 1999, pp.43-52.

LOWEKRON, Laura. Menina ou Moça. Menoridade e consentimento sexual em uma decisao do STF. Trabalho apresentado na $26^{a}$ Reunião Brasileira de Antropologia, realizada em Porto Seguro-BA, 2008a.

. Sexualidade e (Menor)Idade: Estratégias de Controle Social em Diferentes Escalas. Tese de doutorado em Antropologia, PPGAS Museu Nacional, UFRJ, Rio de Janeiro, 2008b.

PELÚCIO, Larissa. Travestis brasileiras: singularidades nacionais, desejos transnacionais. Trabalho apresentado na $26^{a}$ Reuniao brasileira de antropologia, realizada em Porto Seguro-BA, 2008.

SAHLINS, Marshall. A preferência de comida e o tabu nos animais domésticos americanos. In:Cultura e razão prática, Rio de Janeiro, Zahar, 2003.

RUBIN, Gayle. Thinking sex: notes for a radical theory of politics of sexuality. In: VANCE, Carol. (org.) Pleasure and Danger: Exploring Female Sexuality. Nova York, Routledge, 1984.

. The Catacombs: A Temple of the Butthole. In: THOMPSON, Mark. (org.) Leatherfolk: Radical Sex, People, Politics and Practice. Los Angeles, Alyson Books, 2001.

RUSSO, Jane. Do desvio ao transtorno: a medicalização da sexualidade na nosografia psiquiátrica contemporânea. In: PISCITELLI, Adriana, GREGORI, Maria Filomena e CARRARA, Sergio. (orgs.) Sexualidades e saberes: Convenções e fronteiras. Rio de Janeiro, Garamond Universitária, 2004, pp.95-114. 
VANDER VELDEN, F. F. Inquietas Companhias: sobre os animais de criação entre os Karitiana. Tese de Doutorado em Antropologia, IFCH, Universidade Estadual de Campinas, 2010.

. Nota sobre zoofilia na história dos Karitiana. Revista Primeira Versão, ano IX, $\mathrm{n}^{\circ}$ 270, vol XXX, Porto Velho, outubro 2010, pp.3-8.

VergotTI, Mayra. "ireitos animais e o remodelamento das fronteiras políticas entre os mundos humano e não-humano. In: Memórias das Jornadas de Antropologia da Unicamp, 2011. Disponível em: $<$ http://antropologias.descentro.org/seminarioppgas/>

VIANNA, Adriana e LACERDA, Paula. Direitos e políticas sexuais no Brasil: o panorama atual. Rio de Janeiro, CEPESC, 2004.

VigARELLO, Georges. História do Estupro: violência sexual nos séculos XVI-XX. Rio de Janeiro, Zahar, 1998.

Viveiros De CASTRO, E. Araweté: os deuses canibais. Rio de Janeiro, Zahar/ANPOCS, 1986.

ZILLI, Bruno Dallacort. A perversão domesticada: Estudo do discurso de legitimação do BDSM na Internet e seu diálogo com a Psiquiatria. Dissertação de Mestrado em Medicina Social, PPGSC/UERJ, Rio de Janeiro, 2007.

- BDSM da A a Z: A despatologização através do consentimento os 'manuais' da internet. In: DÍAZ-BENÍTEZ, Maria Elvira e FíGARI, Carlos. Prazeres Dissidentes. Rio de Janeiro, Garamond, 2009, pp.481-508. 